\title{
Use of Turkey Meal as a Replacement for Menhaden Fish Meal in Practical Diets for Sunshine Bass Grown in Cages
}

\author{
Kenneth R. Thompson, Linda S. Metts, Laura A. Muzinic, \\ Siddhartha Dasgupta, and Carl D. Webster* \\ Aquaculture Research Center, Kentucky State University, \\ 103 Athletic Drive, Frankfort, Kentucky, 40601, USA \\ YOLANDA J. BRADY \\ Department of Fisheries and Allied Aquaculture, Auburn University, Auburn, Alabama, 36849, USA
}

\begin{abstract}
A 391-d feeding trial was conducted with caged juvenile (mean weight $=36.2 \mathrm{~g}, \mathrm{SD}=8.04 \mathrm{~g}$ ) sunshine bass (female white bass Morone chrysops $\times$ male striped bass $M$. saxatilis) to evaluate growth, feed conversion, protein efficiency ratio, body composition, and fillet composition resulting from diets with decreasing levels of fish meal (FM; 30, 20, 10, and 0\%) and increasing levels of turkey meal (TM; 0.0, 9.7, 17.5 , and $26.4 \%$ ). We stocked 100 randomly selected fish into each of 12 floating cages $\left(3.5 \mathrm{~m}^{3}\right)$. Twice daily, fish were fed all they could consume in $30 \mathrm{~min}$. Four practical diets were formulated to contain $40 \%$ protein and to be isoenergetic. After $391 \mathrm{~d}$, significant $(P \leq 0.05)$ differences were found in growth; fish fed the control diet (30\% FM, 0\% TM) had higher individual final weight, percent weight gain, and specific growth rate than fish fed 10.0\% FM and 17.5\% TM. However, differences for those variables were not apparent between the control group and fish fed the 20\% FM and 9.7\% TM diet or the $0 \%$ FM and 26.4\% TM diet. Diet composition did not significantly alter amount of diet fed, feed conversion ratio, protein efficiency ratio, percent survival, fillet yield, or hepatosomatic index among treatments. Results indicate that sunshine bass grown in cages for $391 \mathrm{~d}$ can be fed a diet containing $0 \% \mathrm{FM}$ and $26.4 \% \mathrm{TM}$ without adverse effects on growth, feed conversion ratio, and body composition; more diverse diet formulations for sunshine bass and reduced usage of menhaden fish meal are therefore possible.
\end{abstract}

Production of sunshine bass (female white bass Morone chrysops $\times$ male striped bass $M$. saxatilis) is one of the fastest growing segments of U. S. aquaculture and is now fifth in volume and fourth in value (US\$28 million in 2005) among all food fish grown in the USA. However, high production cost is the greatest limitation to this industry (Carlberg et al. 2000). The continued expansion of the sunshine bass industry depends in part on diet cost reduction, and one way of reducing diet costs is to decrease or eliminate marine fish meal (FM), which is the most expensive macroingredient ( $>$ US $\$ 800$ per ton) in an aquaculture diet. With the static or declining fish populations that are used to produce FM, any negative disturbance, supply disruption, or availability problem can lead to dramatic increases in the commodity price. Further, the capture of wild fish used to feed cultured fish is thought to be unsustainable by many critics of aquaculture. One approach to reducing FM in sunshine bass diets is to replace it with alternative animal or plant protein ingredients, which will alleviate the

\footnotetext{
* Corresponding author: cwebster@dcr.net
}

Received January 23, 2007; accepted March 16, 2007 Published online September 13, 2007 dependence on marine-derived protein sources, allow for continued expansion of the global aquaculture industry by utilizing renewable ingredients, and help decrease diet costs, thereby potentially increasing profits for sunshine bass producers.

Soybean meal (SBM) is widely known to be a costeffective alternative for high-quality FM in diets for many aquaculture species because of its high protein content, relatively well-balanced amino acid profiles, reasonable price, and steady supply (Lovell 1988; Chou et al. 2004). Lovell (1988) reported that SBM has one of the best amino acid profiles of any plant protein feedstuff. However, sunshine bass diets containing SBM as the sole protein source might be nutritionally inadequate because methionine and lysine are the most limiting amino acids in high-SBM diets (Andrews and Page 1974; Lovell 1989). Other negative factors that may reduce growth when dietary FM is completely replaced by SBM are decreased digestibility of nutrients and reduced palatability if SBM is used at high percentages. It has been reported that the activity of protease (trypsin) inhibitors in crude or inadequately heated SBM may be a reason for reduced growth (Dabrowski and Kozak 1979; Wilson and Poe 1985). However, Webster et al. (1992c) stated that this may not be of practical importance because commercially 
TABLE 1.-Amino acid composition (\%) and proximate composition (\%) of turkey meal (Conagra, Omaha, Nebraska) and poultry by-product meal (PBM; feed grade [FG] and petfood grade [PFG]).

\begin{tabular}{|c|c|c|c|}
\hline Component & Turkey meal & PBM-FG & PBM-PFG \\
\hline \multicolumn{4}{|c|}{ Amino $\operatorname{acids}^{\mathbf{a}}$} \\
\hline Alanine & 4.0 & & \\
\hline Arginine & 4.8 & 4.5 & 4.8 \\
\hline Aspartic acid & 5.5 & & \\
\hline Cystine & 2.0 & & \\
\hline Glutamic acid & 8.7 & & \\
\hline Glycine & 5.6 & & \\
\hline Histidine & 1.3 & 1.4 & 1.4 \\
\hline Isoleucine & 3.0 & 2.0 & 2.2 \\
\hline Leucine & 5.2 & 4.0 & 4.4 \\
\hline Lysine & 3.3 & 3.4 & 3.8 \\
\hline Methionine & 0.8 & 1.1 & 1.3 \\
\hline Phenylalanine & 3.1 & 2.2 & 2.3 \\
\hline Proline & 5.5 & & \\
\hline Serine & 4.8 & & \\
\hline Threonine & 2.7 & 2.1 & 2.4 \\
\hline Tyrosine & 2.0 & & \\
\hline Valine & 4.2 & 2.3 & 2.5 \\
\hline \multicolumn{4}{|c|}{ Proximate analysis (dry-matter basis) ${ }^{\mathrm{a}}$} \\
\hline Moisture & 8.6 & 5.0 & 5.0 \\
\hline Protein & 66.6 & 65.0 & 68.0 \\
\hline Lipid & 11.1 & 14.0 & 16.0 \\
\hline Fiber & 1.3 & & \\
\hline Ash & 8.6 & 14.0 & 10.0 \\
\hline
\end{tabular}

${ }^{a}$ Amino acid composition and proximate analysis of turkey meal were determined by a commercial analytical laboratory (Eurofins Scientific, Inc., Des Moines, Iowa).

available SBM usually has little trypsin inhibitor activity if adequately processed. Likewise, SBM is deficient in available phosphorus; although SBM contains approximately $0.7 \%$ phosphorus, only about one-third to one-half is biologically usable by fish (Lovell 1988). Thus, inclusion of an animal protein source, combined with SBM, may assist in the formulation of diets involving total replacement of FM. Webster et al. (1992a, 1992b, 1999) stated that combining plant and animal source proteins with complementary amino acid profiles may help avoid any deficiency or limitation that could negatively impact fish performance.

Poultry by-product meal (PBM) is one animal byproduct feedstuff that is effective for fully or partially replacing FM in aquaculture diets. Webster et al. (1999) reported that growth was similar between sunshine bass fed a diet containing PBM and SBM as complete replacements for FM from menhaden Brevoortia spp. and those fed a control diet with $30 \%$ FM. However, in a subsequent study, Webster et al. (2000) reported that sunshine bass fed a diet with PBM and SBM had significantly lower growth than those fed a 30\% FM diet. The PBM used in the two studies may have originated from different sources or differed in processing methods or quality (Webster et al. 2000). Muzinic et al. (2006) reported that turkey meal (TM), a by-product of the turkey industry, may be an important ingredient for FM replacement in aquaculture diets because of its high protein content, balanced amino acid profiles (Table 1), and lower cost (when available) than FM. However, little published data are available on the use of TM in aquaculture diets and only one published report describes its use in sunshine bass diets (Muzinic et al. 2006).

Sunshine bass can be grown in a variety of culture systems, including ponds, tanks, or cages. Although cage culture represents a small percentage $(<5 \%)$ of the total U.S. sunshine bass production, it is an intensive production method that allows for growing of fish in ponds that may otherwise be difficult to harvest, either due to irregularly shaped pond bottoms, shoreline contour, or presence of debris and obstacles. Previous cage research reported acceptable growth rates and high $(>85 \%)$ survival of sunshine bass (Webster et al. 1995c, 1997a, 2001).

Cages have several advantages over open-pond culture systems for growing sunshine bass: low initial investment, reduced labor, and more efficient use of existing pond space. However, use of cages reduces the availability of natural foods and may alter nutritional specifications of the diet (Lovell 1973). Reduction or elimination of FM in diets fed to cage-grown sunshine bass could adversely affect growth. Webster et al. (1997a) reported that cage-grown palmetto bass (male white bass $\times$ female striped bass) could be fed diets with $15-45 \%$ FM, but those fed a diet containing SBM and meat-and-bone meal but no FM had reduced growth.

In a recent 2006 survey, small (350-450-g) sunshine bass were presented to chefs in Kentucky; many chefs liked the smaller fish, particularly whole-dressed fish, which are considered to be more of a specialty item than fillets (authors' unpublished data). This would allow producers to market fish in a shorter period, which could assist in cash flow and reduce liability (fish dieoffs). The objective of this study was to evaluate growth, feed efficiency, and body composition of cage-grown sunshine bass fed practical diets in which TM progressively replaced FM on a percent protein basis.

\section{Methods}

Experimental diets.-Sunshine bass were fed four diets consisting of 2.0-mm floating pellets produced by extrusion at Integral Fish Foods, Inc. (Grand Junction, Colorado). All diets were formulated to be isonitrogenous ( $40 \%$ protein dry-matter basis) and isoenergetic (available energy $[\mathrm{AE}]=4.0 \mathrm{kcal} / \mathrm{g}$ of diet) and to meet 
the known amino acid requirements of sunshine bass (Tables 2, 3). The four experimental diets were formulated to contain decreasing FM amounts and increasing TM amounts. Because TM digestible protein values are not known for hybrid striped bass and PBM digestibility values for sunshine bass were not reported when our diets were formulated, TM was substituted for FM on an isonitrogenous basis. Diet 1 was formulated to be similar to a commercial high-quality finfish diet containing 0\% TM and 30\% menhaden FM, diet 2 contained $9.7 \%$ TM and $20 \%$ FM, diet 3 contained $17.5 \% \mathrm{TM}$ and $10.0 \% \mathrm{FM}$, and diet 4 contained 26.4\% TM and 0\% FM. Because proximate composition of the dietary ingredients differed from tabular values (NRC 1993), diets varied somewhat in actual chemical analysis from calculated values.

Diet analysis.-Diets were analyzed based on standard procedures (AOAC International 1995) to determine percent moisture (a 2-g sample was placed in a convection oven at $135^{\circ} \mathrm{C}$ for $2 \mathrm{~h}$ until constant weight was achieved), protein (combustion method), lipid (acid hydrolysis method), fiber (fitted-glass crucible method), and ash (a 2-g sample was placed in a muffle furnace at $600^{\circ} \mathrm{C}$ for $2 \mathrm{~h}$ ). The nitrogen-free extract (NFE; i.e. carbohydrate) was determined by difference: $\mathrm{NFE}=100-(\%$ protein $+\%$ lipid $+\%$ fiber $+\%$ ash). The $\mathrm{AE}$ was calculated from physiological fuel values of $4.0,4.0$, and $9.0 \mathrm{kcal} / \mathrm{g}$ for protein, carbohydrate (NFE), and lipid, respectively (Garling and Wilson 1977; Webster et al. 1999). Proximate composition and amino acid composition of the diets (Tables 2, 3) and of TM (Table 1) were determined by a commercial analytical laboratory (Eurofins Scientific, Inc., Des Moines, Iowa).

Water quality management.-During June-October 2004 and April-July 2005, water temperature and dissolved oxygen (DO) outside the cages (at a depth of $0.75 \mathrm{~m}$ ) were measured twice daily (0830 and 1530 hours) with a YSI oxygen meter (Yellow Springs Instruments, Yellow Springs, Ohio; Model 57). From November 2004 to March 2005, water temperature and DO were measured sporadically and only in the afternoons (1530 hours) because declining water temperatures translated to reduced feeding activity. If DO was graphically predicted to decline below $4.0 \mathrm{mg}$ / $\mathrm{L}$, aeration was provided with a 5-hp electric paddlewheel (S\&N Sprayer, Co., Inc., Greenwood, Mississippi). Several water variables were not measured because previous studies in this pond (Webster et al. 1992a, 1995c, 1997a, 1997b) showed very consistent averages: $0.17 \mathrm{mg} / \mathrm{L}$ for total ammonia nitrogen, $0.01 \mathrm{mg} / \mathrm{L}$ for nitrite, 8.8 for $\mathrm{pH}$, and $105 \mathrm{mg} / \mathrm{L}$ for alkalinity.

Experimental system and feeding.- The feeding trial was conducted in 12 floating cages $\left(3.5 \mathrm{~m}^{3}\right)$ placed over
TABLE 2.- Ingredient and analyzed chemical composition (\%) of four practical diets containing different levels of turkey meal (Conagra, Omaha, Nebraska) as a replacement for fish meal and fed to juvenile sunshine bass. Proximate analysis values are means of two replications per diet.

\begin{tabular}{|c|c|c|c|c|}
\hline \multirow[b]{2}{*}{ Component } & \multicolumn{4}{|c|}{ Diet } \\
\hline & 1 (control) & 2 & 3 & 4 \\
\hline \multicolumn{5}{|c|}{ By ingredient } \\
\hline Menhaden fish meal & 30.0 & 20.0 & 10.0 & 0.0 \\
\hline Soybean meal & 31.5 & 30.6 & 31.9 & 31.8 \\
\hline Turkey meal & 0.0 & 9.7 & 17.5 & 26.4 \\
\hline Wheat flour & 10.0 & 10.0 & 10.0 & 10.0 \\
\hline Corn meal & 20.6 & 21.8 & 22.7 & 23.9 \\
\hline Menhaden fish oil & 4.0 & 4.0 & 4.0 & 4.0 \\
\hline Monocalcium phosphate & 1.0 & 1.0 & 1.0 & 1.0 \\
\hline Stay C & 0.2 & 0.2 & 0.2 & 0.2 \\
\hline Choline chloride & 0.5 & 0.5 & 0.5 & 0.5 \\
\hline Vitamin and mineral mix $^{\mathrm{a}}$ & 2.0 & 2.0 & 2.0 & 2.0 \\
\hline Ethoxyquin & 0.02 & 0.02 & 0.02 & 0.02 \\
\hline Mold inhibitor & 0.2 & 0.2 & 0.2 & 0.2 \\
\hline \multicolumn{5}{|c|}{ By analyzed composition (dry matter basis) } \\
\hline Moisture (\%) & 6.8 & 6.0 & 7.5 & 7.3 \\
\hline Protein $(\%)$ & 40.5 & 39.4 & 38.2 & 39.6 \\
\hline Lipid $(\%)$ & 10.1 & 10.3 & 9.9 & 10.7 \\
\hline Fiber (\%) & 2.0 & 2.2 & 2.2 & 2.3 \\
\hline Ash (\%) & 9.4 & 8.0 & 7.1 & 7.2 \\
\hline $\mathrm{NFE}^{\mathrm{b}}$ & 38.0 & 40.1 & 42.6 & 40.2 \\
\hline Available energy $(\mathrm{kcal} / \mathrm{g})^{\mathrm{b}}$ & 4.00 & 4.06 & 4.07 & 4.08 \\
\hline$E: P^{b}$ & 10.0 & 10.4 & 10.8 & 10.5 \\
\hline
\end{tabular}

$\overline{{ }^{a} \text { Rangen trace mineral mix for catfish contained } 0.3 \mathrm{mg} \text { selenium } / \mathrm{kg}}$ of diet added. Abernathy vitamin premix number 2 supplied the following per kilogram of diet: biotin $=0.60 \mathrm{mg}, \mathrm{B}_{12}=0.06 \mathrm{mg}, \mathrm{E}$ (as alpha-tocopherol acetate $)=50 \mathrm{IU}$, folic acid $=16.5 \mathrm{mg}$, myo-inositol $=$ $132 \mathrm{mg}, \mathrm{K}$ (as menadione sodium bisulfate complex) $=9.2 \mathrm{mg}$, niacin $=221 \mathrm{mg}$, pantothenic acid $=106 \mathrm{mg}, \mathrm{B}_{6}=31 \mathrm{mg}$, riboflavin $=53 \mathrm{mg}$, thiamin $=43 \mathrm{mg}, \mathrm{D}_{3}=440 \mathrm{IU}$, and $\mathrm{A}$ (as vitamin A palmitate $)=4,399$ IU.

${ }^{\mathrm{b}} \mathrm{NFE}=$ nitrogen-free extract; $\mathrm{E}: \mathrm{P}=$ calculated energy $:$ protein ratio; available energy was calculated as $4.0,4.0$, and $9.0 \mathrm{kcal} / \mathrm{g}$ for protein, carbohydrate, and lipid, respectively.

the deepest area $(4 \mathrm{~m})$ of a 1.0-ha pond (average depth $=$ $2.0 \mathrm{~m}$ ) located at the Agricultural Research Farm, Kentucky State University, Frankfort. Each cage had a frame made of polyvinylchloride (PVC) tubing with a removable lid and was constructed of $10-\mathrm{mm}$ polyethylene mesh. A polyethylene mesh panel (0.2-mm mesh, $20 \mathrm{~cm}$ high) was installed around the top of the inside of each cage to prevent loss of floating diet, even during aggressive feeding periods. Cages were anchored to a floating dock; the distance between cages was $2 \mathrm{~m}$. In April, all cage sides were cleaned with a brush to remove algae and freshwater sponges; additional cleaning was unnecessary because there was little fouling of the mesh during the summer growing seasons.

Juvenile sunshine bass were obtained from Jones Fish and Lake Management (Newtown, Ohio) via Keo Fish Farm (Keo, Arkansas) and were stocked at an average weight of $36.2 \mathrm{~g}(\mathrm{SD}=8.04)$. We stocked 100 fish into each of the 12 cages (i.e., 4 diets, 3 replicate 
TABLE 3.-Amino acid composition (\%) of four practical sunshine bass diets (Table 2) containing various levels of turkey meal as a partial or total replacement for fish meal. Known amino acid requirements (\%) for sunshine bass are indicated. The amount of amino acid expressed as a percentage of the dietary protein is given in parentheses.

\begin{tabular}{|c|c|c|c|c|c|}
\hline \multirow[b]{2}{*}{ Amino acid } & \multirow[b]{2}{*}{ Requirement $^{\mathrm{a}}$} & \multicolumn{4}{|c|}{ Diet } \\
\hline & & 1 (control) & 2 & 3 & 4 \\
\hline Alanine & & 2.29 & 2.22 & 2.16 & 2.29 \\
\hline Arginine & $1.55(4.4)$ & $2.70(6.7)$ & $2.68(6.8)$ & $2.72(7.1)$ & $2.75(6.9)$ \\
\hline Aspartic acid & & 6.55 & 6.25 & 6.10 & 6.18 \\
\hline Cystine & & 0.46 & 0.58 & 0.62 & 0.71 \\
\hline Glutamic acid & & 6.81 & 6.63 & 6.68 & 6.83 \\
\hline Glycine & & 2.52 & 2.52 & 2.50 & 2.73 \\
\hline Histidine & & 1.05 & 0.98 & 0.95 & 0.98 \\
\hline Isoleucine & & 1.67 & 1.65 & 1.65 & 1.68 \\
\hline Leucine & & 3.10 & 3.07 & 3.06 & 3.18 \\
\hline Lysine & $1.41(4.0)$ & $2.66(6.6)$ & $2.39(6.1)$ & $2.26(5.9)$ & $2.26(5.7)$ \\
\hline Methionine & & 0.76 & 0.70 & 0.61 & 0.62 \\
\hline Total sulfur amino acids & $\begin{array}{l}0.73(2.1) \\
1.0(2.9)\end{array}$ & $1.22(3.0)$ & $1.28(3.3)$ & $1.23(3.2)$ & $1.33(3.4)$ \\
\hline Phenylalanine & & 1.87 & 1.85 & 1.87 & 1.94 \\
\hline Proline & & 2.43 & 2.62 & 2.53 & 3.14 \\
\hline Serine & & 2.12 & 2.30 & 2.34 & 2.54 \\
\hline Threonine & $0.9(2.6)$ & $1.92(4.7)$ & $1.89(4.8)$ & $1.85(4.8)$ & $1.91(4.8)$ \\
\hline Tyrosine & & 1.29 & 1.26 & 1.27 & 1.27 \\
\hline Valine & & 1.92 & 1.97 & 1.97 & 2.09 \\
\hline
\end{tabular}

a Source: Griffin et al. (1994b) for arginine; Griffin et al. (1992) and Keembiyehetty and Gatlin (1992) for lysine; Griffin et al. (1994a) for total sulfur amino acids (TSAA; 0.73\%); Keembiyehetty and Gatlin (1993) for TSAA (1.0\%); and Keembiyehetty and Gatlin (1997b) for threonine.

cages/diet). For a period of $391 \mathrm{~d}$, at 0800 and 1600 hours each day, fish were given all the feed they would consume in $30 \mathrm{~min}$ (Webster et al. 2001). After $178 \mathrm{~d}$, approximately $10-14$ fish were netted from each cage and weighed to obtain early growth data. Fish were handled with care and promptly restocked into their respective cages to minimize stress.

The amount of diet fed per cage was weighed (nearest $0.1 \mathrm{~g}$ ) during the entire production cycle. At the conclusion of the feeding trial, 10 fish/cage were randomly sampled and chill-killed by lowering the body temperature in an ice bath. Fish were kept frozen $\left(-20^{\circ} \mathrm{C}\right)$ until analysis. Whole-body weight was measured (nearest $0.1 \mathrm{~g}$ ), intraperitoneal fat (free of connective tissue and liver) was removed and weighed separately, and fillets were removed from the backbone (no skin and ribcage) and weighed. Notably, fillets were excised by the same person throughout final sampling. Fillets from 3 fish/cage were chopped, stored in polyethylene bags, and frozen for subsequent protein, lipid, ash, and moisture analyses.

Growth performance, feed conversion, and body analysis were measured in terms of percent weight gain (PWG), specific growth rate (SGR; \% change per day), percent survival, feed conversion ratio (FCR), protein efficiency ratio (PER), percent IPF, percent fillet weight (PFW), and hepatosomatic index (HSI) as follows:

$$
\mathrm{SGR}=\left[\left(\log _{e} W_{t}-\log _{e} W_{i}\right) / T\right] \times 100,
$$

where $W_{t}$ is the weight of fish at time $t, W_{i}$ is the weight of fish at time 0 , and $T$ is the culture period (d);

$$
\begin{gathered}
\mathrm{PWG}=100 \times\left[\left(W_{t}-W_{i}\right) / W_{i}\right], \\
\mathrm{FCR}=\frac{\text { total dry weight of diet fed }}{\text { total wet weight gain }},
\end{gathered}
$$

where wet weight and feed weight are in kilograms;

$$
\text { PER = weight gain/protein fed, }
$$

where weight gain and protein fed are in kilograms;

$$
\mathrm{IPF}=\left(\frac{\text { wet weight of abdominal fat }}{\text { wet weight of fish }}\right) \times 100,
$$

where wet weights are in grams;

$$
\mathrm{PFW}=\left(\frac{\text { wet weight of fillet }}{\text { wet weight of fish }}\right) \times 100,
$$

where wet weights are in grams;

$$
\text { HSI }=\left(\frac{\text { wet weight of liver }}{\text { wet weight of fish }}\right) \times 100,
$$

where both weights are in grams.

Statistical analysis.-Data were analyzed by oneway analysis of variance (ANOVA) using the general linear models (GLM) procedure in the Statistical Analysis System version 8.2 (SAS Institute 1999) to determine whether growth, diet fed (grams per fish), FCR, PER, survival percentage, body composition, and 
TABLE 4.-Monthly mean ( \pm SE) morning (AM) and afternoon (PM) dissolved oxygen and water temperature in a pond (Agricultural Research Farm, Kentucky State University, Frankfort) containing cage-grown sunshine bass fed practical diets with various levels of turkey meal as a partial or total replacement for fish meal.

\begin{tabular}{|c|c|c|c|c|}
\hline \multirow{2}{*}{$\begin{array}{c}\text { Month } \\
\text { and year }\end{array}$} & \multicolumn{2}{|c|}{ Dissolved oxygen $(\mathrm{mg} / \mathrm{L})$} & \multicolumn{2}{|c|}{ Temperature $\left({ }^{\circ} \mathrm{C}\right)$} \\
\hline & $\mathrm{AM}$ & $\mathrm{PM}$ & $\mathrm{AM}$ & $\mathrm{PM}$ \\
\hline \multicolumn{5}{|c|}{2004} \\
\hline Jun & $7.0 \pm 0.32$ & $9.3 \pm 0.28$ & $26.3 \pm 0.16$ & $27.3 \pm 0.21$ \\
\hline Jul & $7.3 \pm 0.25$ & $10.5 \pm 0.39$ & $25.5 \pm 0.20$ & $26.4 \pm 0.22$ \\
\hline Aug & $8.3 \pm 0.30$ & $11.4 \pm 0.39$ & $23.7 \pm 0.24$ & $24.8 \pm 0.21$ \\
\hline Sep & $7.7 \pm 0.37$ & $9.8 \pm 0.25$ & $24.4 \pm 0.39$ & $23.6 \pm 0.35$ \\
\hline Oct & $9.0 \pm 0.0$ & $9.8 \pm 0.49$ & $16.9 \pm 0.0$ & $17.3 \pm 0.54$ \\
\hline \multicolumn{5}{|c|}{2005} \\
\hline Apr & $9.8 \pm 0.0$ & $11.1 \pm 1.16$ & $20.5 \pm 0.0$ & $16.3 \pm 1.53$ \\
\hline May & $7.9 \pm 0.87$ & $11.4 \pm 1.55$ & $22.5 \pm 0.26$ & $21.8 \pm 1.24$ \\
\hline Jun & $5.7 \pm 0.62$ & $8.4 \pm 0.24$ & $26.0 \pm 1.17$ & $28.1 \pm 0.39$ \\
\hline Jul & $5.8 \pm 0.22$ & $7.6 \pm 0.47$ & $26.9 \pm 0.22$ & $28.9 \pm 0.11$ \\
\hline
\end{tabular}

proximate fillet muscle were significantly different among treatments. Significant differences between treatment means were separated by Tukey's studentized range (honestly significant difference) test. All percentage and ratio data were arcsine transformed before analysis (Zar 1984). Significance level $\alpha$ was set at 0.05 . Data are presented as untransformed values.

\section{Water Quality}

\section{Results}

Average morning and afternoon DO and water temperature during the first (June-October 2004) and second (April-July 2005) growing seasons were within acceptable limits for fish growth and health (Table 4; Boyd 1979; Webster et al. 2001). Afternoon water temperature and DO from November 2004 to March 2005 averaged $10.1^{\circ} \mathrm{C}$ and $12.8 \mathrm{mg} / \mathrm{L}$, respectively.

\section{Growth and Production}

After $178 \mathrm{~d}$, there were no significant $(P>0.05)$ differences in mean final weight (390.4 g), PWG (978.5\%), SGR (5.33\% per day), estimated amount of diet fed (826.6 g/fish), and estimated FCR (2.36) among treatments (Table 5). However, when analyzed from the beginning of the study until harvest $(391 \mathrm{~d}$ total), some significant $(P<0.05)$ differences were found in growth. Fish fed diet 1 (control) had a higher individual final weight (548 g), PWG (1,414\%), and SGR $(0.69 \%$ per day) than fish fed diet 3 (462.8 g, $1,179 \%$, and $0.65 \%$ per day, respectively). Control values did not differ from those of fish fed diet 2 (483.1 $\mathrm{g}, 1,235 \%$, and $0.66 \%$ per day) or diet $4(510.4 \mathrm{~g}$, $1,310 \%$, and $0.68 \%$ per day). Overall, there were no significant among-treatment differences in mean amount of diet fed (1,196.5 g/fish), FCR (2.59), PER (0.99), and survival (88.2\%) at harvest.

\section{Body Index and Fillet Proximate Composition}

Fillet yield (PFW) was not significantly different among dietary treatments and averaged $28.4 \%$ of body weight (Table 5). Likewise, HSI was not significantly different among dietary treatments and averaged 1.74 (Table 5). However, the IPF percentage in sunshine bass fed diet $3(5.0 \%)$ was significantly higher than that

TABLE 5.-Mean ( \pm SE) estimated final weight, percent weight gain, specific growth rate (SGR), estimated amount of diet fed, estimated feed conversion ratio (FCR), protein efficiency ratio (PER), percent survival, percent intraperitoneal fat (IPF), fillet yield, and hepatosomatic index (HSI) of juvenile sunshine bass fed practical diets (Table 2) containing various levels of turkey meal as a partial or total replacement for fish meal. Within a row, means followed by different letters are significantly different $(P$ $<0.05)$.

\begin{tabular}{|c|c|c|c|c|c|}
\hline \multirow{2}{*}{$\begin{array}{c}\text { Experimental } \\
\text { period }\end{array}$} & \multirow[b]{2}{*}{ Variable } & \multicolumn{4}{|c|}{ Diet } \\
\hline & & 1 (control) & 2 & 3 & 4 \\
\hline \multirow[t]{5}{*}{ Jun-Dec 2004} & Final weight (g) & $414.7 \pm 27.1 \mathrm{z}$ & $369.5 \pm 28.3 \mathrm{z}$ & $386.4 \pm 13.9 \mathrm{z}$ & $390.9 \pm 38.8 \mathrm{z}$ \\
\hline & Weight gain $(\%)$ & $1,046 \pm 75 \mathrm{z}$ & $921 \pm 78 \mathrm{z}$ & $967 \pm 38 \mathrm{z}$ & $980 \pm 107 \mathrm{z}$ \\
\hline & SGR $(\% / d)$ & $1.37 \pm 0.04 \mathrm{z}$ & $1.30 \pm 0.04 \mathrm{z}$ & $1.33 \pm 0.02 \mathrm{z}$ & $1.33 \pm 0.06 \mathrm{z}$ \\
\hline & Diet fed (g/fish) & $846.5 \pm 22.8 \mathrm{z}$ & $798.7 \pm 31.5 \mathrm{z}$ & $825.1 \pm 15.3 \mathrm{z}$ & $836.1 \pm 31.4 \mathrm{z}$ \\
\hline & FCR & $2.25 \pm 0.10 \mathrm{z}$ & $2.44 \pm 0.29 \mathrm{z}$ & $2.37 \pm 0.14 \mathrm{z}$ & $2.37 \pm 0.14 \mathrm{z}$ \\
\hline \multirow[t]{10}{*}{ Jun 2004-Jul 2005} & Final weight (g) & $548 \pm 20.3 \mathrm{z}$ & $483.1 \pm 18 \mathrm{zy}$ & $462.8 \pm 8.0 \mathrm{y}$ & $510.4 \pm 5.3 \mathrm{zy}$ \\
\hline & Weight gain $(\%)$ & $1,414 \pm 57 \mathrm{z}$ & $1,235 \pm 49 \mathrm{zy}$ & $1,179 \pm 22 \mathrm{y}$ & $1,310 \pm 15 \mathrm{zy}$ \\
\hline & SGR $(\% / d)$ & $0.69 \pm 0.01 \mathrm{z}$ & $0.66 \pm 0.01 \mathrm{zy}$ & $0.65 \pm 0.01 \mathrm{y}$ & $0.68 \pm 0.003 \mathrm{zy}$ \\
\hline & Diet fed (g/fish) & $1,294.5 \pm 87.8 \mathrm{z}$ & $1,145.6 \pm 68.8 \mathrm{z}$ & $1,205.7 \pm 51.9 \mathrm{z}$ & $1,140.2 \pm 21.5 \mathrm{z}$ \\
\hline & FCR & $2.53 \pm 0.11 \mathrm{z}$ & $2.59 \pm 0.19 \mathrm{z}$ & $2.65 \pm 0.15 \mathrm{z}$ & $2.59 \pm 0.20 \mathrm{z}$ \\
\hline & PER & $0.98 \pm 0.04 \mathrm{z}$ & $0.99 \pm 0.02 \mathrm{z}$ & $0.92 \pm 0.04 \mathrm{z}$ & $1.05 \pm 0.03 \mathrm{z}$ \\
\hline & Survival (\%) & $90.3 \pm 3.5 \mathrm{z}$ & $86.7 \pm 3.9 \mathrm{z}$ & $88.7 \pm 7.7 \mathrm{z}$ & $87.0 \pm 8.3 \mathrm{z}$ \\
\hline & $\operatorname{IPF}(\%)^{\mathrm{a}}$ & $4.4 \pm 0.3 \mathrm{zy}$ & $4.0 \pm 0.2 \mathrm{y}$ & $5.0 \pm 0.3 \mathrm{z}$ & $4.6 \pm 0.2 \mathrm{zy}$ \\
\hline & Fillet yield $(\%)^{\mathrm{a}}$ & $28.6 \pm 0.4 \mathrm{z}$ & $28.0 \pm 0.5 \mathrm{z}$ & $29.1 \pm 0.6 \mathrm{z}$ & $28.0 \pm 0.4 \mathrm{z}$ \\
\hline & $\mathrm{HSI}^{\mathrm{a}}$ & $1.63 \pm 0.06 \mathrm{z}$ & $1.67 \pm 0.05 \mathrm{z}$ & $1.77 \pm 0.05 \mathrm{z}$ & $1.87 \pm 0.09 \mathrm{z}$ \\
\hline
\end{tabular}

\footnotetext{
${ }^{a}$ Values are based on 3 replications and 10 fish/replicate.
} 
TABLE 6.-Mean ( \pm SE) percent moisture, protein, lipid, and ash (as-is basis) in fillet muscle of juvenile sunshine bass fed practical diets (Table 2) containing various levels of turkey meal as a partial or total replacement for fish meal, means within all rows were not significantly different $(P>0.05)$.

\begin{tabular}{lcccc}
\hline \multirow{2}{*}{$\begin{array}{c}\text { Diet } \\
\text { component }\end{array}$} & 1 (control) & 2 & 3 & 4 \\
\cline { 2 - 5 } & $73.3 \pm 0.7$ & $72.9 \pm 0.5$ & $73.0 \pm 0.6$ & $72.9 \pm 0.6$ \\
\hline Moisture & $20.1 \pm 0.4$ & $20.7 \pm 0.6$ & $20.2 \pm 0.4$ & $20.7 \pm 0.7$ \\
Protein & $4.39 \pm 0.6$ & $4.00 \pm 0.2$ & $4.78 \pm 0.7$ & $4.07 \pm 0.8$ \\
Lipid & $1.18 \pm 0.02$ & $1.14 \pm 0.01$ & $1.15 \pm 0.04$ & $1.15 \pm 0.0$ \\
Ash & & & & \\
\hline
\end{tabular}

of fish fed diet $2(4.0 \%)$ but not significantly different from that of fish fed diet $1(4.4 \%)$ or diet $4(4.6 \%)$. There were no significant differences among treatments in terms of moisture $(73.0 \%)$, protein $(20.4 \%)$, lipid ( $4.31 \%)$, or ash $(1.16 \%$; as-is basis) content of fillets (Table 6).

\section{Discussion}

After $391 \mathrm{~d}$ in cages, mean final individual weight, PWG, SGR, amount of diet fed, FCR, PER, and percent survival of sunshine bass fed a diet containing $26.4 \% \mathrm{TM}, 32.0 \% \mathrm{SBM}$, and $0 \% \mathrm{FM}$ were similar to those of fish fed a diet containing 30\% FM and 32\% SBM. Furthermore, little to no differences in IPF percentage, fillet percentage, and HSI were found. Our data indicate that TM is a suitable ingredient for use in sunshine bass diets and may, when combined with $\mathrm{SBM}$, serve as an alternate protein source to completely replace FM. Our results agree with those of Muzinic et al. (2006), who found that tank-grown sunshine bass could be fed a diet in which TM totally replaced FM without adverse effects on growth, feed efficiency, and body composition. However, their study was of a shorter duration and the fish were smaller at the conclusion of the feeding trial (maximum average weight $=375 \mathrm{~g}$ in their study, $548 \mathrm{~g}$ in our study). Because new markets are emerging for smaller $(<550$ g) sunshine bass, our study may assist producers who supply these markets in providing a lower cost, nutritious diet option that has the potential to increase profitability.

Because of its high nutritional value and palatability, FM is usually the main or the only protein source for carnivorous marine fish species (Tacon 1994). Webster et al. (1997a) reported that a diet containing $15 \%$ FM was sufficient for diet palatability and good growth in juvenile palmetto bass grown in cages for $125 \mathrm{~d}$, whereas a diet containing $0 \%$ FM was not; however, the final individual weight and SGR of fish fed a diet containing $0 \% \mathrm{FM}, 38.9 \%$ SBM, and $36.5 \%$ meat-andbone meal were significantly lower than those of fish fed diets containing 15, 30, and 45\% FM. Because the FM amino acid profile is nearly ideal and supports rapid growth in Morone species, the current hybrid striped bass diet formulations contain a sizable quantity of FM, often exceeding $25 \%$ of the protein requirement (Gaylord and Rawles 2005). Although marine FM is a highly desirable animal protein ingredient for many fish species, there is a monetary benefit in reducing or eliminating FM in sunshine bass diets because FM is one of the most expensive dietary ingredients. Further, there are concerns about the uncertain availability and sustainability of FM use in the future. Therefore, continued expansion of the sunshine bass industry depends on developing production diets that decrease FM dependence (i.e., partial or total reduction in FM percentage) without adverse growth and health effects on the cultured species.

Recent studies on the use of PBM as replacement for FM in hybrid striped bass diets (Gaylord et al. 2004; Gaylord and Rawles 2005; Rawles et al. 2006) have prompted inclusion of PBM in commercial diets for sunshine bass, but at limited rates so as to avoid adverse effects on fish growth. Rawles et al. (2006) stated that one limitation to incorporating substantial levels of PBM in carnivorous fish diets stems from factors related to product source and processing, conditions that can radically affect specific amino acid availability in rendered products. Dong et al. (1993) found that proximate composition and protein digestibility of PBM from various manufacturers often differed from reported tabular values (NRC 1993). The PBM source and processing conditions can greatly affect specific amino acid availability (Parsons et al. 1997; Wang and Parsons 1998; Bureau et al. 1999). Muzinic et al. (2006) reported that differences in the amounts of less-nutritious body parts included in animal by-product meals, along with differences in processing conditions (heating temperature and duration), can alter the nutrient quality of the ingredient and can greatly affect the digestibility and availability of protein and amino acids. We did not determine the effects of TM processing methods on nutritional quality, but the TM's amino acid composition and the demonstrated growth of sunshine bass indicate that the TM was of good nutritional value. The TM we used 
was of high nutritional quality at $66.6 \%$ protein and $11.1 \%$ lipid, and the percentage ash was less than that of PBM (Table 1). Levels of arginine, isoleucine, phenylalanine, threonine, and valine in the TM were higher than those in PBM, whereas levels of histidine, lysine, and methionine were only somewhat lower (Table 1). Ours are the first findings to indicate that TM may be an important ingredient for replacing FM for sunshine bass grown to reach a size considered desirable for the pan-size market.

Protein quality of an ingredient is essential when formulating diets for an organism so that the diet (ingredient) supplies essential amino acids (EAA) for the organism's metabolic requirements. This includes the total amino acid composition of the ingredients, as well as the bioavailability of the amino acids. Nengas et al. (1999) reported that PBM can be deficient in one or more EAAs for gilthead seabream Sparus aurata, which has reduced bioavailability of protein and essential amino acids to sunshine bass (Gaylord et al. 2004), largemouth bass Micropterus salmoides (Portz and Cyrino 2004); and rainbow trout Oncorhynchus mykiss (Dong et al. 1993). Gaylord and Rawles (2005) reported that pet-food-grade PBM fortified with lysine and methionine appeared to be a nutritionally viable replacement for all FM in diets for sunshine bass. However, they concluded that pet-food-grade PBM alone (at $40 \%$ digestible protein) was insufficient to meet the amino acid requirements of sunshine bass. In our study, a diet containing a combination of TM and SBM as the primary protein sources without amino acid supplementation appeared to have met the EAA requirements of sunshine bass, as indicated by growth, feed efficiency, and body composition. No dietary amino acid deficiencies were apparent, and EAA levels were similar to those of the control diet.

As is the case for other by-product meals, the quality consistency of TM can depend upon the amount of indigestible components in the meal (e.g., feathers or a higher percentage of bone) and the processing method; however, the availability and cost of TM are other factors to consider. Turkey meal is currently available for sale only occasionally, but if demand increases the supply could become more consistent (D. Brock, Rangen, Buhl, Idaho, personal communication). Although the exact cost of TM depends on location and availability, it is usually $\$ 20-100$ less per ton than PBM (TM is regarded as inferior because it usually has higher ash content) and approximately \$400-500 less per ton than FM.

Percent weight gain, SGR, and FCR in our study were similar to those in other studies (Hughes et al. 1992; Nematipour et al. 1992; Keembiyehetty and Gatlin 1997a; Webster et al. 1999, 2000; Muzinic et al.
2006). The PERs, which ranged from 0.92 to 1.05 , were similar to the value of 1.18 reported for sunshine bass grown in aquaria for 8 weeks on a diet of $0 \% \mathrm{FM}$, $32 \%$ SBM, and 28\% PBM (Webster et al. 1999)and to reported values for carnivorous fish (Webster et al. 1992c, 1995b, 1995c; Tidwell et al. 2005). Further, the amount of diet fed did not differ significantly among dietary treatments, which might explain why FCR and PER were unaffected by treatments.

Information on numerous aspects of the nutritional requirements of juvenile sunshine bass has been described, and all diets used in our study apparently met published requirements (Webster 2002). However, it is unclear why fish fed diet $3(10 \%$ FM and $17.5 \%$ TM) had significantly lower final weight, PWG, and SGR than those fed the control diet, whereas no differences were found between the control group and fish fed diets 2 and 4. Amino acid composition was similar among diets 2-4 (Table 3), which indicates that the availability of essential amino acids should have been comparable. The reduced growth of sunshine bass fed diet 3 is thus not readily explained. A possible reason for these results may be a lower percentage protein in diet 3; however, that is unlikely given that the dietary amino acid concentrations for both indispensable and dispensable amino acids were similar among all treatments. Furthermore, there should have been no quality differences if the same dietary protein sources were used for all the diets.

The IPF percentage (range $=4.0-5.0 \%$ ) did not differ significantly among treatments, and the values agreed with other reported values of 3.1-7.2\% (Nematipour et al. 1992; Keembiyehetty and Gatlin 1997b; Keembiyehetty and Wilson 1998; Webster et al. 2000; Muzinic et al. 2006). Fillet yields (28.0-29.1\%) were similar among treatments but lower than other reports for sunshine bass, probably due to interstudy differences in filleting techniques and final fish size. Nematipour et al. (1992) reported that fillet yield was between $40 \%$ and $45 \%$ of whole-body weight, and Gallagher (1994) reported a fillet yield of $34 \%$. The fish $(>500 \mathrm{~g})$ we used were larger than those used by Nematipour et al. (1992) and Gallagher (1994) but similar in size to fish used by Webster et al. (1995c, 1997, 1999, 2000, 2001) and Muzinic et al. (2006). Although the fillet yield in our study may have been lower than some reports, there should be no variation within our study attributable to filleting technique or portion of muscle obtained. Fillet proximate composition (moisture, protein, lipid, and ash) did not differ among treatments, and values are similar to previously published reports (Zhang et al. 1994; Webster et al. 1997a, 2000; Muzinic et al. 2006). Whole-body analysis indicated that HSI values in our study were 
similar to or lower than those reported by others (Nematipour et al. 1992; Webster et al. 1995c, 1997a; Keembiyehetty and Wilson 1998; Muzinic et al. 2006).

Results indicate that a diet containing $40 \%$ protein and formulated to contain $0 \% \mathrm{FM}, 26.4 \% \mathrm{TM}$, and $32.0 \%$ SBM was sufficient for sunshine bass; that is, the diet did not produce adverse effects on growth, survival, or body composition of fish grown in cages. In diet 4, TM and SBM replaced $100 \%$ of the FM, yet this formulation appeared to meet nutrient requirements for sunshine bass because growth, body composition, and feed efficiency were similar to those produced by a high-FM diet. Diet 4 seemed to be palatable and provided good digestibility of protein and energy. The TM we used may be a suitable alternative ingredient to FM. Our findings may help reduce diet costs for U.S. sunshine bass producers, thereby lowering production costs. Likewise, this study may benefit those producers targeting pan-size or whole-dress sunshine bass, which are considered a specialty item by some chefs in the USA. Reducing production costs may allow for U.S. aquaculture industry expansion by reducing the reliance on FM in diets of cultured fish.

\section{Acknowledgments}

The authors thank N. Ann, K. N. Dee, B. R. Lee, E. M. Maa, C. Rhin, B. Rett, M. S. Tee, D. R. Wynne, and S. Wise for technical assistance; C. Mayo for feeding and water quality assistance; and J. Greene, R. Janes, and D. Yancey for help in harvesting. This research project was partially funded by a U.S. Department of Agriculture (USDA) Initiative for Future Agriculture and Food Systems grant awarded to Kentucky State University; a USDA 1890 Institution Capacity Building Grant; and a USDA grant under agreement KYX80-00-10A to Kentucky State University.

\section{References}

Andrews, J. W., and J. W. Page. 1974. Growth factors in the fish meal component of catfish diets. Journal of Nutrition 104:1091-1096.

AOAC International. 1995. Official methods of analysis, 16th edition. AOAC International, Arlington, Virginia.

Boyd, C. E. 1979. Water quality in warmwater fish ponds. Auburn University Agriculture Experiment Station, Auburn, Alabama.

Bureau, D. P., A. M. Harris, and C. Y. Cho. 1999. Apparent digestibility of rendered animal protein ingredients for rainbow trout (Oncorhynchus mykiss). Aquaculture 180:345-358.

Carlberg, J. M., J. C. V. Olst, and M. J. Massingil. 2000. Hybrid striped bass: an important fish in the U.S. aquaculture. Aquaculture Magazine 26(5):26-38.

Chou, R. L., B. Y. Her, M. S. Su, G. Hwang, Y. H. Wu, and H. Y. Chen. 2004. Substituting fish meal with soybean meal in diets of juvenile cobia Rachycentron canadum. Aquaculture 229:325-333.

Dabrowski, K., and B. Kozak. 1979. The use of fish meal and soybean meal as a protein source in the diet of grass carp fry. Aquaculture 18:107-114.

Dong, F. M., R. W. Hardy, N. F. Haard, R. T. Barrows, B. A. Rasco, W. T. Fairgrieve, and I. P. Forster. 1993. Chemical composition and protein digestibility of poultry by-product meals for salmonid diets. Aquaculture 116:149-158.

Gallagher, M. L. 1994. The use of soybean meal as a replacement for fish meal in diets for hybrid striped bass (Morone saxatilis $\times M$. chrysops). Aquaculture 126:114127.

Garling, D. L., and R. P. Wilson. 1977. Effect of dietary carbohydrate on growth and body composition of fingerling channel catfish. Progressive Fish-Culturist 39:43-47.

Gaylord, T. G., and S. D. Rawles. 2005. The modification of poultry by-product meal for use in hybrid striped bass Morone chrysops $\times$ M. saxatilis diets. Journal of the World Aquaculture Society 36:363-374.

Gaylord, T. G., S. D. Rawles, and D. M. Gatlin III. 2004. Amino acid availability from animal, blended, and plant feedstuffs for hybrid striped bass (Morone chrysops $\times M$. saxatilis). Aquaculture Nutrition 10:345-352.

Hughes, S. G., C. A. Lemm, and R. L. Herman. 1992. Development of a practical diet for juvenile striped bass. Transactions of the American Fisheries Society 121:802809.

Keembiyehetty, C. N., and D. M. Gatlin III. 1997a. Performance of sunshine bass fed soybean meal based diets supplemented with different methionine compounds. Progressive Fish-Culturist 59:25-30.

Keembiyehetty, C. N., and D. M. Gatlin III. 1997b. A dietary threonine requirement of juvenile hybrid striped bass (Morone chrysops $\times$ M. saxatilis). Aquaculture Nutrition 3:217-221.

Keembiyehetty, C. N., and R. P. Wilson. 1998. Effect of water temperature on growth and nutrient utilization on sunshine bass (Morone chrysops $\times$ M. saxatilis) fed diets containing different energy/protein ratios. Aquaculture 166:151-162.

Lovell, T. 1973. Protein requirements of cage-cultured channel catfish. Proceedings of the Annual Conference Southeastern Association of Game and Fish Commissioners 26(1972):357-361.

Lovell, T. 1988. Use of soybean products in diets for aquaculture species. Journal of Aquatic Products 2:2752.

Lovell, T. 1989. Nutrition and feeding of fish. Van NostrandReinhold, New York.

Muzinic, L. A., K. R. Thompson, L. S. Metts, S. Dasgupta, and C. D. Webster. 2006. Use of turkey meal as partial and total replacement of fish meal in practical diets for sunshine bass (Morone chrysops $\times M$. saxatilis) grown in tanks. Aquaculture Nutrition 12:71-81.

Nematipour, G. R., M. L. Brown, and D. M. Gatlin III. 1992. Effects of dietary energy : protein ratio on growth characteristics and body composition of hybrid striped bass Morone chrysops $\times$ M. saxatilis. Aquaculture 107:359-368. 
Nengas, I., M. N. Alexis, and S. J. Davies. 1999. High inclusion levels of poultry meals and related by-products in diets for gilthead seabream, Sparus aurata. Aquaculture 179:13-23.

NRC (National Research Council). 1993. Nutrient requirements of fish. National Academy Press, Washington, D.C.

Parsons, C. M., F. Castanon, and Y. Han. 1997. Protein and amino acid quality of meat-and-bone meal. Poultry Science 76:361-368.

Portz, L., and J. E. P. Cyrino. 2004. Digestibility of nutrients and amino acids of different protein sources in practical diets by largemouth bass Micropterus salmoides (Lacepede, 1802). Aquaculture Research 35:312-320.

Rawles, S. D., M. Riche, T. G. Gaylord, J. Webb, D. W. Freeman, and M. Davis. 2006. Evaluation of poultry byproduct meal in commercial diets for hybrid striped bass (Morone chrysops $\times$ M. saxatilis) in recirculated tank production. Aquaculture 259:377-389.

SAS Institute. 1999. SAS/STAT software, version 8.2. SAS Institute, Cary, North Carolina.

Tacon, A. G. J. 1994. Feed ingredients for carnivorous fish species: alternatives to fishmeal and other dietary resources. FAO Fisheries Circular 881.

Tidwell, J. H., S. D. Coyle, L. A. Bright, and D. Yasharian. 2005. Evaluation of plant and animal source proteins for replacement of fish meal in practical diets for largemouth bass Micropterus salmoides. Journal of the World Aquaculture Society 36:454-462.

Wang, R. G., and C. M. Parsons. 1998. Effect of raw material source, processing systems, and processing temperatures on amino acid digestibility of meat and bone meals. Poultry Science 77:834-841.

Webster, C. D. 2002. Hybrid striped bass. Pages 327-343 in C. D. Webster and C. E. Lim, editors. Nutrient requirements and feeding of finfish for aquaculture. CABI Publishing, Oxon, UK.

Webster, C. D., L. S. Goodgame-Tiu, and J. H. Tidwell. 1995a. Total replacement of fish meal by soybean meal, with various percentages of supplemental L-methionine, in diets for blue catfish, Ictalurus furcatus (Lesueur). Aquaculture Research 26:299-306.

Webster, C. D., K. R. Thompson, A. M. Morgan, and E. J. Grisby. 2001. Feeding frequency affects growth, not fillet composition, of juvenile sunshine bass Morone chrysops $\times M$. saxatilis grown in cages. Journal of the World Aquaculture Society 32:79-88.

Webster, C. D., K. R. Thompson, A. M. Morgan, E. J. Grisby, and A. L. Gannam. 2000. Use of hempseed meal, poultry by-product meal, and canola meal in practical diets without fish meal for sunshine bass (Morone chrysops $\times$ M. saxatilis). Aquaculture 188:299-309.

Webster, C. D., J. H. Tidwell, L. G. Tiu, and D. H. Yancey. 1995b. Use of soybean meal as partial or total substitute of fish meal in diets for blue catfish (Ictalurus furcatus). Aquatic Living Resources 8:379-384.

Webster, C. D., J. H. Tidwell, and D. H. Yancey. 1992a. Effect of protein level and feeding frequency on growth and body composition of cage-reared channel catfish. Progressive Fish-Culturist 54:92-96.

Webster, C. D., J. H. Tidwell, and D. H. Yancey. 1992b. Effect of feeding diets containing 34 and $38 \%$ protein at two feeding frequencies on growth and body composition of channel catfish. Journal of Applied Aquaculture 1(3):67-80.

Webster, C. D., L. G. Tiu, A. M. Morgan, and A. L. Gannam. 1999. Effect of partial and total replacement of fish meal on growth and body composition of sunshine bass Morone chrysops $\times$ M. saxatilis fed practical diets. Journal of the World Aquaculture Society 30:443-453.

Webster, C. D., L. G. Tiu, and J. H. Tidwell. 1997a. Effects of replacing fish meal in diets on growth and body composition of palmetto bass (Morone saxatilis $\times M$. chrysops) raised in cages. Journal of Applied Aquaculture 7(1):53-67.

Webster, C. D., L. G. Tiu, and J. H. Tidwell. 1997b. Growth and body composition of juvenile hybrid bluegill Lepomis cyanellus $\times$ L. macrochirus fed practical diets containing various percentages of protein. Journal of the World Aquaculture Society 28:230-240.

Webster, C. D., L. G. Tiu, J. H. Tidwell, P. Van Wyk, and R. D. Howerton. 1995c. Effects of dietary protein and lipid levels on growth and body composition of sunshine bass (Morone chrysops $\times M$. saxatilis) reared in cages. Aquaculture 131:291-301.

Webster, C. D., D. H. Yancey, and J. H. Tidwell. 1992c. Effect of partially or totally replacing fish meal with soybean meal on growth of blue catfish (Ictalurus furcatus). Aquaculture 103:141-152.

Wilson, R. P., and W. E. Poe. 1985. Effects of feeding soybean meal with varying trypsin inhibitor activities on growth of fingerling channel catfish. Aquaculture 46:1925.

Zar, J. H. 1984. Biostatistical analysis. Prentice-Hill, Englewood Cliffs, New Jersey.

Zhang, Q., R. C. Reigh, and W. R. Wolters. 1994. Growth and body composition of pond-raised hybrid striped basses, Morone saxatilis $\times M$. chrysops and $M$. saxatilis $\times M$. mississippiensis, fed low and moderate levels of dietary lipid. Aquaculture 125:119-129. 